\title{
Hepatocyte Nuclear Factor 3-Alpha
}

National Cancer Institute

\section{Source}

National Cancer Institute. Hepatocyte Nuclear Factor 3-Alpha. NCI Thesaurus. Code C101648.

Hepatocyte nuclear factor 3-alpha (472 aa, $49 \mathrm{kDa}$ ) is encoded by the human FOXA1 gene. This protein plays a role in the modulation of transcription. 